\title{
Risk and Real Estate Ownership: Empirical Evidence of Hotels in Singapore
}

\author{
Fawzia Farzana* \\ Dr. Md. Ghulam Murtaza ${ }^{* *}$
}

\begin{abstract}
This paper examined the impact of real property ownership on the systematic risk of hotel companies in Singapore. This issue is interesting because few studies have been carried out on this topic. The hypothesis is that the real estate ownership would impose negative effect on the systematic risk of company in hotel sector because corporate real estate is commonly considered as an instrument for diversification in a mixed portfolio. To examine the effect, two-stage least-square regression was applied. The data was collected from published sources and other data streams. The results indicate that real estate ownership has impact on the systematic risk of companies. The implication is that the different strategies of companies may result in the different directions of impacts.
\end{abstract}

\section{Introduction}

Corporate real estate refers to the land and buildings owned by companies not primarily in the real estate business. Along with capital and labor, real estate is often regarded as the third factor of production (Liow, 1995:13). Especially in the hotel sector, property plays an instrumental role in the well-being of its management. It is not simply a vehicle to accommodate a production process; in addition, property is a major asset on many hotel corporations' financial statements in UK (Liow, 1995:13). In Singapore context, Liow also have done some preliminary studies and found that real assets is relatively more important in the balance sheet of hotels companies compare to other non-real estate business sectors (Liow, 1999:4). However, there are very little empirical studies which concern on the relationship among risk, return and real asset-holding.

The aim of this study is to anatomize the impact of real property ownership on systematic risk in hotel sector. This is because corporate real estate is thought to be closer to the core activity in hotel business than in many other sectors. This article reports on a research focusing on the hotels in Singapore.

\section{Literature Review}

There are numerous studies that examine the performance of real estate assets. Han and Liang (1995) provide a comprehensive review of such studies. Two decades ago, researchers began to focus on the largely unrecognized importance of corporate real asset-holding to many businesses. This appeal for attention and respect was advanced in a number of articles and research studies (Estey, 1988:4; Veale, 1989:1; Nourse and Roulac, 1993:475; Apgar, 1995:2; Duckworth, 1993:409; Joroff, Louargand, Lambert and Becker, 1993; Becker and Joroff, 1995; Roulac and Roberts, 1990), which pointed out how significant property was on the corporate balance sheet and just how large was the component of operating expenses that property services represented.

Zeckhauser and Silverman (1983:111) reported that American companies' real estate typically accounts for at least $25 \%$ of their total assets is worth in aggregate between $\$ 700$ billion and $\$ 1.4$ trillion - a sum equal to, or greater than the wealth of the nation's pension funds. Since this great value, the authors claimed that every corporation should have the need to rethink real estate

\footnotetext{
* Assistant Professor, E-mail: tuli_nus@yahoo.com

** Professor, Urban and Rural Planning Discipline, Khulna University, Khulna

E-mail: smgmurtaza@gmail.com
} 
holdings which cuts across boundaries of company size or business activity, the quantity and value of property held, or its geographic distribution. And they said that research studies have shown that the proper management of real estate assets by any company can make a significant, positive short-term as well as long-term impact.

Manning and Roulac (1996:265) reviews the tasks a corporate real estate (CRE) function should undertake to create more opportunities for a company's real estate-related decisions to increase shareholder wealth. Finally, they pointed that additional research in the area of corporate real estate has the potential for providing the greatest assistance to corporate real estate executives to explore, expand and customize their services for greater impact on their company's strategic planning and shareholder wealth. Carn, Black and Rabianski (1999:281) show that coping with downsizing, mergers, rapid globalization, international competition and fast paced economic challenges on one hand, and soaring technological, regulatory and environmental impacts on the other, American corporations are carefully reexamining and restructuring many of their operations, including the corporate real estate (CRE) function. As a primary support system for American business, the CRE function is heavily involved in devising new strategies and blazing new pathways for more efficient and productive operations consistent with the goals and objectives of their core business.

Barry (1999:113) described the corporate real estate (CRE) portfolio in three perspectives, and then the paper identifies the need for a portfolio approach to the management of real estate assets, and set out its key components as a 'marco' level process. Among the significant researches on corporate property, Hill (2001:335) has presented the pros and cons of owning property and finally he examined how corporate occupiers can manage the contribution of their operational properties make to shareholders value. Meanwhile, other researches called attention to the corporate property strategy. These realized the powerful intersecting relationship of corporate real estate strategy, place and space contributions and summarized the sources of competitive advantage. Among them, Roulac (2001:129) reported that a superior corporate property strategy impacts and produces positive outcomes in employee satisfaction, production factor economics, business opportunities realized and forgone, risk management considerations, and other impacts on enterprise value.

Furthermore, Seiler, Chatrath and Webb (2001:199) put attention in another field of corporate real estate which is the impact of real asset ownership on the systematic risk and risk-adjusted return of corporations. All of above literatures have studied and analyzed variance directions in the field of corporate real estate, however, there is a lack of attention to the relationship between the return from real estate and the risk corporations faced in particular business sector. Though Virginia and Barkham (2001:107) have done some studies in the retail sector, they focused their research on the management of corporate real estate. This lacks evidence on the relationship between risk and return in the area of corporate real estate.

Due to the realization about the relationship between the real assets and hotel companies' operations, it is decided to study on hotel sector and this research provides additional insights into the "real estate" influences of hotel corporations. The hypothesis is that the real estate holdings would impose negative impact on the systematic risk of a company in hotel sector, because corporate real estate is commonly considered as an instrument for diversification in a mixed portfolio. In order to analyze this impact, four factors that are considered to have effect on the systematic risk of a company have been included in the model. They are the size, the leverage, the property asset intensity and the change of market value of a company. 


\section{Methodology}

The four factors indicated above were assumed to have linear relationship with the systematic risk of a company. Therefore, the data have been analyzed applying the two-stage least square regression. In the regression model, the systematic risk was considered as the dependent variable and the four factors were regarded as the independent variables, which was expressed as following:

$\beta_{t}=\alpha_{0}+\alpha_{1} R A_{t}+\alpha_{2} L E V_{t}+\alpha_{3} \ln T A_{t}+\alpha_{4}(\Delta \mathrm{M})+\varepsilon_{t}$

where $\beta_{t}$ represents the annual estimates of beta at time t. $R A_{t}$ is the property asset intensity. The property asset intensity is the percentage of the property value (include both land and buildings; both leasehold and freehold) to the total assets in the balance sheet. $L E V_{t}$ is the leverage ratio, which is the long-term liabilities divided by the total assets. The percentages of the leverage ratio in the regression mode were taken. $\ln T A_{t}$ illustrates the size of a company. $T A_{t}$ is the total assets of the company in the balance sheet. The natural logarithm of the total assets is used as a proxy of the size of a company. $\Delta M$ denotes the annually change of market value of the shares of a company. $\varepsilon_{t}$ is the regression error term.

The regression model was applied to estimate the coefficients of the four indicated factors of five companies. In fact, there were altogether twenty one companies listed in the SGX MAINBOARD or SGX SESDAQ under the hotel/restaurant sector. Within these companies, eighteen companies had prime business in hotel sector. Among these hotel companies, only five companies had the complete time series data the study needed. The data used was from 1983 to 2001 . The data earlier than 1983 were considered to have more regression points for companies. However, the earlier data for some companies was not available especially for the dependent variable in the model, $\beta_{t}$.

The time series data of the systematic risk of the five companies was collected from the financial highlights which are a series of books containing time series highlighted financial data for the listed companies on SGX (The books were published by Centre for Business Research \& Development, FBA, NUS). The total assets, total properties and long-term liabilities of the companies were gathered from the annual reports of the companies. The market value of shares was accessed in the data stream which contains the statistical data and time series financial data provided by the Bloomberg.

\section{Data Analysis}

Table 1 provides a summary on how the four indicated variables influence the systematic risks. The main purpose of the study was to estimate if holding real estate has negative effect on the firm's systematic risk. As table 1 shows, the Overseas Union has $\alpha_{1}$ of -2.27 , which means its percentage of real estate holding has remarkable negative impact on its beta. For this company, a change in the percentage of the firm's real estate holdings will lead to a greater inverse change in its systematic beta if the other factors remain the same. Furthermore, in Sea View and Apollo's case, real estate holdings have significant negative effect on beta, with $\alpha_{1}$ of -1.52 and -0.57 respectively. However, although the influences are still great, Grand Central and Negara have positive $\alpha_{1}$ of 0.87 and 0.78 . Figure 1 presents a whole view of influence of percentage of real estate holding on each firm's systematic risk. As a result, it can be said that real estate ownership does impose impacts on beta significantly, but according to the results, this study cannot draw the conclusion whether the impacts are positive or negative to a company as the different strategies of companies with respect to the management and operation of properties may generate opposite directions of the relationship between the property asset intensity and the systematic risk. 
Table 1: The influences of four indicated variables on systematic risks

\begin{tabular}{|l|c|c|c|c|c|}
\hline \multicolumn{1}{|c|}{ Indicator } & $\begin{array}{l}\text { Percentage of real } \\
\text { estate holding } \\
\text { company }\end{array}$ & leverage & Corporate size & $\begin{array}{c}\text { Change rate } \\
\text { of market } \\
\text { value }\end{array}$ & Constant \\
\hline $\begin{array}{l}\text { Apollo Enterprise } \\
\text { Limited }\end{array}$ & -0.57 & -1.03 & -1.09 & 0.22 & 3.44 \\
\hline $\begin{array}{l}\text { Hotel Grand } \\
\text { Centre }\end{array}$ & 0.87 & 1.86 & -0.17 & 0.001 & 4.04 \\
\hline Hotel Negara & 0.78 & 0.08 & -0.11 & 0.02 & 1.60 \\
\hline Overseas Union & -2.27 & -0.80 & -1.02 & 0.10 & 22.93 \\
\hline Sea View Hotel & -1.52 & 1.65 & -2.00 & -0.04 & 37.28 \\
\hline
\end{tabular}

Another interesting finding of this study is that leverage influences beta impose positive effect on the systematic risk significantly. As shown in Table 1, Grand Central has $\alpha_{2}$ of 1.86 and Sea View has $\alpha_{2}$ of 1.65. These findings are expected results. However, out of our expectation, the leverage ratios of Apollo and Overseas Union impose significant negative impact on their systematic risks. The coefficients are -1.03 , and -0.80 respectively.

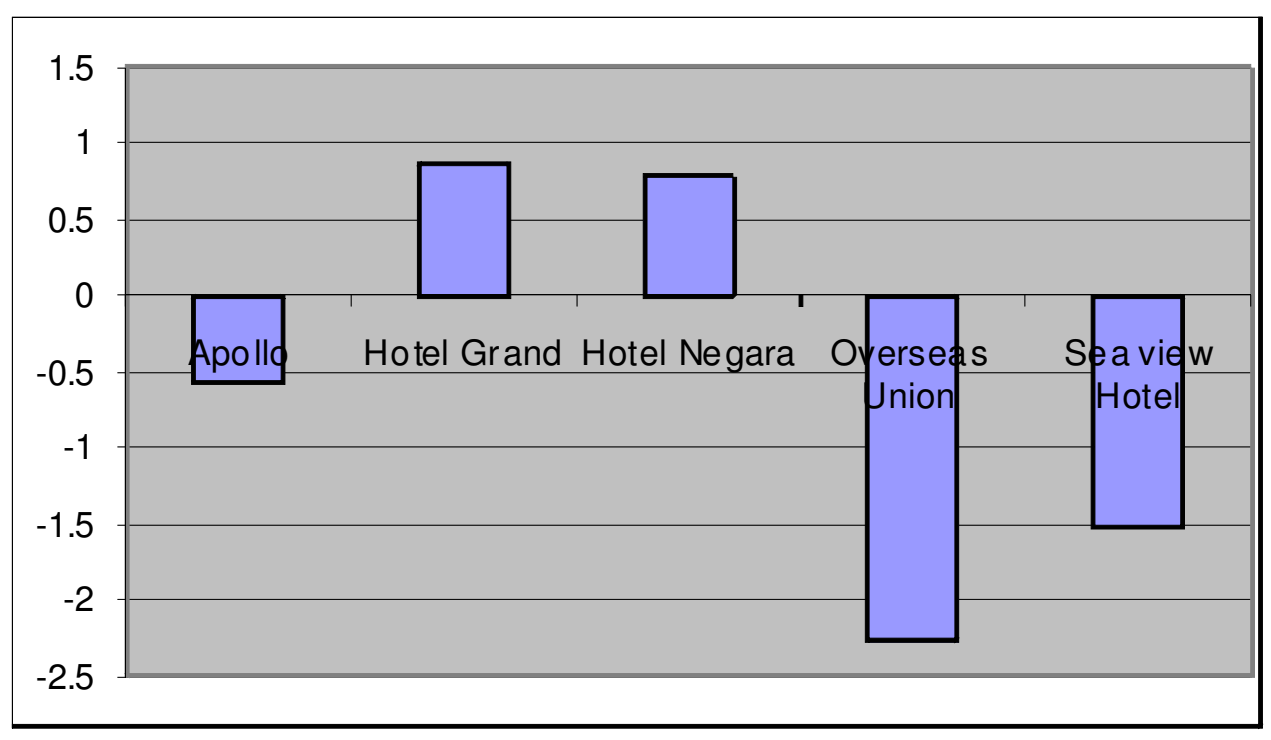

Fig. 1: Influence of real estate holdings on systematic risks.

The study also examines if higher real estate holdings will lead to higher firm's systematic risk. From Table 2, it can be observed that it is not necessary in case of all hotels. In case of Sea view Hotel, its high real estate holdings expose it to a higher systematic risk (above 2 in the first four years) than other four companies. However, Hotel Negara, whose systematic risk is always the lowest among the five companies, holds real estate always above $45 \%$ during the time period from 1986 to 2001. Also, it is not surprising that Hotel Grand Centre, whose property intensity is always low, has an average systematic risk of 1.1039 during our research period. A direct and clear picture of these observations can be observed from Figure 2 (A-E). 
Table 2: Contrasting between $\beta$ and property holdings

\begin{tabular}{|c|c|c|c|c|c|c|c|c|c|c|}
\hline \multirow{2}{*}{ Year } & \multicolumn{2}{|c|}{$\begin{array}{l}\text { Hotel Grand } \\
\text { Centre }\end{array}$} & \multicolumn{2}{|c|}{ Hotel Negara } & \multicolumn{2}{|c|}{ Overseas Union } & \multicolumn{2}{|c|}{$\begin{array}{l}\text { Apollo Enterprise } \\
\text { Limited }\end{array}$} & \multicolumn{2}{|c|}{ Sea View Hotel } \\
\hline & $\square$ & $\begin{array}{l}\% \text { of } \\
\text { CRE }\end{array}$ & $\square$ & \%of CRE & $\square$ & \%of CRE & $\square$ & $\%$ of CRE & $\square$ & \% of CRE \\
\hline 1983 & 1.3703 & $17.8 \%$ & & $45.0 \%$ & 1.8801 & $26.0 \%$ & 1.2622 & $29.1 \%$ & 2.2436 & $48.1 \%$ \\
\hline 1984 & 1.3568 & $16.3 \%$ & & $44.6 \%$ & 1.8854 & $23.5 \%$ & 1.2635 & $27.2 \%$ & 2.3024 & $43.7 \%$ \\
\hline 1985 & 1.069 & $14.8 \%$ & & $45.9 \%$ & 1.8243 & $21.5 \%$ & 1.3772 & $26.0 \%$ & 2.6214 & $43.3 \%$ \\
\hline 1986 & 0.5867 & $13.3 \%$ & -0.0978 & $46.0 \%$ & 1.6873 & $21.8 \%$ & 0.2605 & $31.2 \%$ & 2.1627 & $44.6 \%$ \\
\hline 1987 & 0.7934 & $13.4 \%$ & 0.1125 & $54.04 \%$ & 1.6738 & $21.0 \%$ & 0.9001 & $32.7 \%$ & 1.9431 & $41.8 \%$ \\
\hline 1988 & 0.9027 & $13.0 \%$ & 0.1377 & $54.6 \%$ & 1.7053 & $20.0 \%$ & 1.214 & $33.0 \%$ & 2.124 & $40.6 \%$ \\
\hline 1989 & 0.9097 & $15.4 \%$ & 0.2037 & $53.8 \%$ & 1.6605 & $22.3 \%$ & 1.4311 & $32.4 \%$ & 2.0733 & $37.1 \%$ \\
\hline 1990 & 1.2415 & $21.0 \%$ & 0.2027 & $53.1 \%$ & 1.5964 & $25.0 \%$ & 1.0865 & $30.1 \%$ & 1.7965 & $34.8 \%$ \\
\hline 1991 & 1.2928 & $20 \%$ & 0.3998 & $72.3 \%$ & 1.4705 & $24.2 \%$ & 1.3041 & $27.2 \%$ & 1.5355 & $46.4 \%$ \\
\hline 1992 & 1.3065 & $20.5 \%$ & 0.263 & $79.0 \%$ & 1.4935 & $22.2 \%$ & 1.1175 & $25.0 \%$ & 1.3392 & $39.5 \%$ \\
\hline 1993 & 0.962 & $16.1 \%$ & 0.266 & $78.9 \%$ & 1.487 & $21.2 \%$ & 0.978 & $57.5 \%$ & 1.1132 & $33.9 \%$ \\
\hline 1994 & 0.96 & $13.4 \%$ & 0.208 & $95.5 \%$ & 1.475 & $20.0 \%$ & 1.036 & $13.5 \%$ & 0.885 & $31.2 \%$ \\
\hline 1995 & 1.119 & $11.1 \%$ & 0.341 & $64.0 \%$ & 1.239 & $19.3 \%$ & 1.027 & $73.8 \%$ & 0.616 & $31.7 \%$ \\
\hline 1996 & 0.95 & $10.2 \%$ & 0.08 & $64.5 \%$ & 1.06 & $18.7 \%$ & 0.951 & $65.4 \%$ & 0.44 & $29.7 \%$ \\
\hline 1997 & 0.858 & $11.4 \%$ & 0.387 & $63.3 \%$ & 1.145 & $15.3 \%$ & 0.959 & $63.6 \%$ & 0.604 & $22.2 \%$ \\
\hline 1998 & 1.13 & $11.7 \%$ & -0.154 & $64.1 \%$ & 1.462 & $15.5 \%$ & 0.804 & $63.2 \%$ & 0.763 & $23.1 \%$ \\
\hline 1999 & 1.369 & $9.6 \%$ & -0.086 & $65.4 \%$ & 1.377 & $14.2 \%$ & 0.755 & $64.6 \%$ & 1.025 & $23.9 \%$ \\
\hline 2000 & 1.384 & $9.7 \%$ & -0.075 & $64.8 \%$ & 1.382 & $13.6 \%$ & 0.643 & $64.3 \%$ & 1.089 & $25.1 \%$ \\
\hline 2001 & 1.412 & $9.3 \%$ & -0.08 & $63.5 \%$ & 1.376 & $10.9 \%$ & 0.701 & $65.6 \%$ & 1.104 & $25.4 \%$ \\
\hline
\end{tabular}

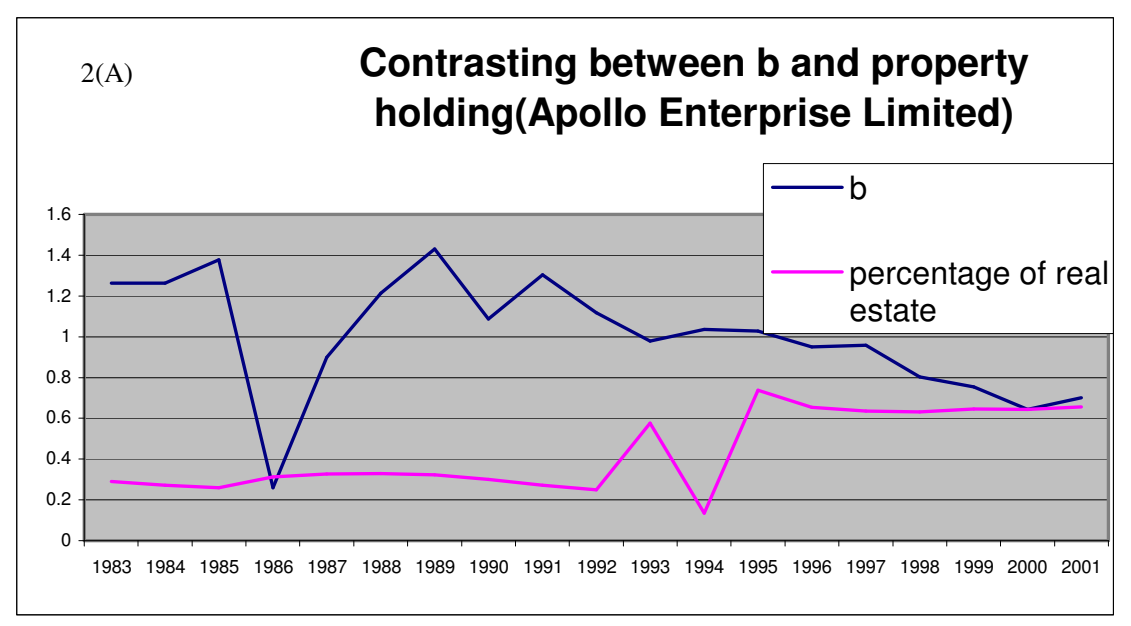



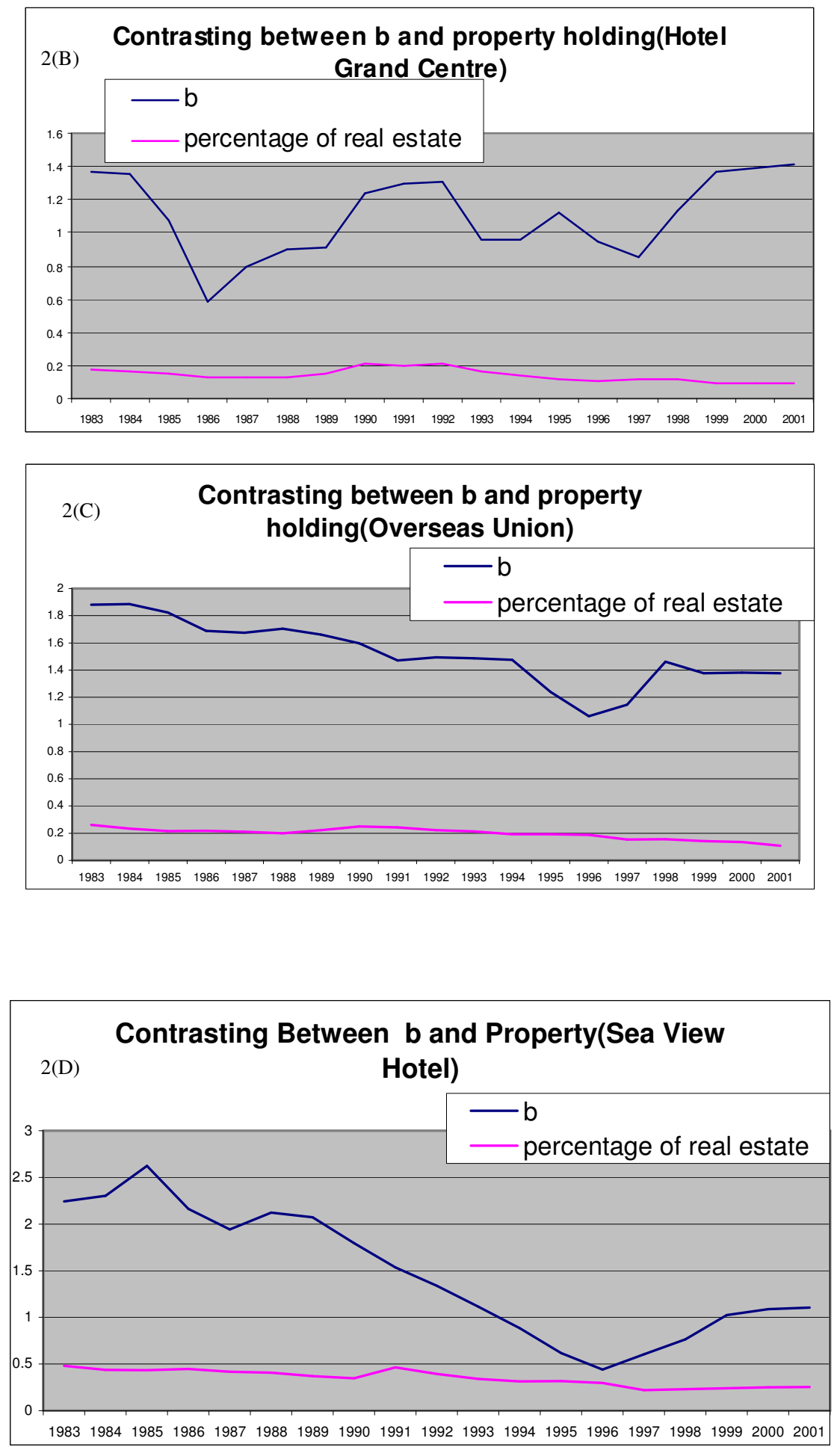


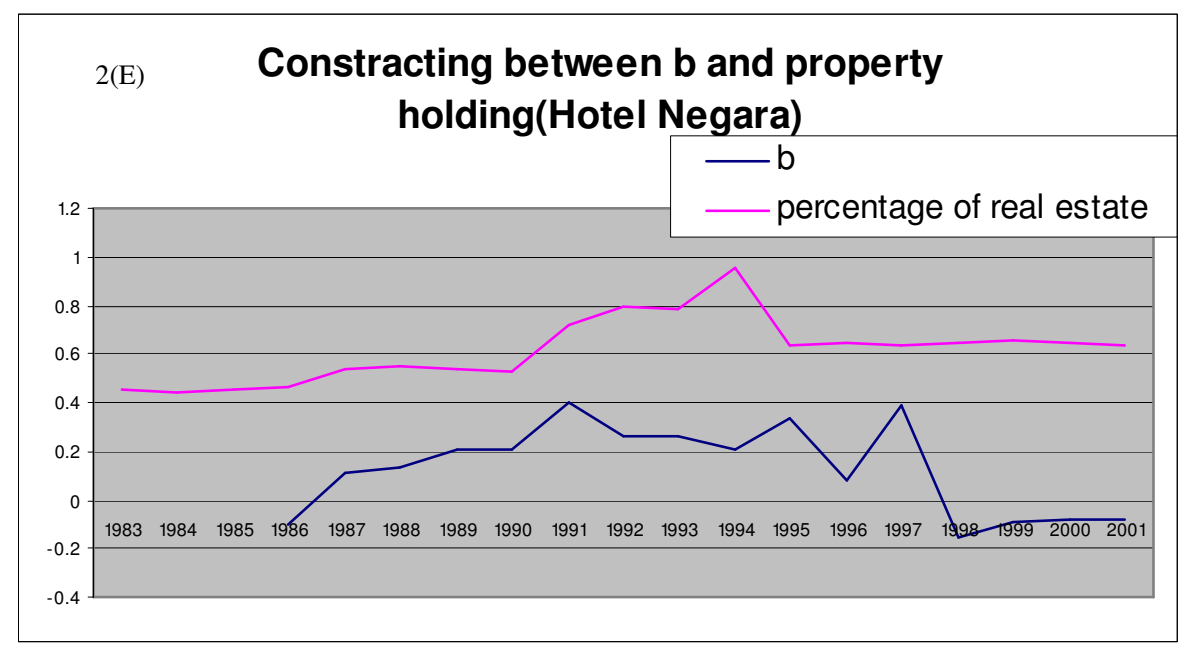

Fig. 2 (A-E): contrasting between $\beta$ and property holdings of different hotels.

\section{Conclusion}

This paper examined the impact of real property ownership on systematic risk in hotel sector. This issue is interesting because while real assets is deemed relatively more important in the balance sheet of hotels companies than other non-real estate business sectors, there are very few empirical studies addressing the relationship among risk, return and real asset-holding. The hypothesis is that the ownership of real assets would make diversified benefits for corporate companies by providing a lower systematic risk or a higher risk-adjusted return. In order to examine the effect of real asset holdings of a corporate company, a regression was carefully designed and performed. All required financial data were collected from the annual reports, financial highlights and data stream. The time span is from 1983 to 2001. Five companies of which data for these variables was available were included in the study. The results indicate that real estate ownership impacts systematic risk significantly. Although further research is needed to clarify that the direction is positive or not, which was not analyzed due to limited data resources available in this study. The second finding is that leverage influences systematic risk heavily in positive direction. The implication is that real property ownership imposes significant impacts on systematic risk in the hotel sector.

However, there are also some limitations in this research. Firstly, in the hotel sector of Singapore, there are only 11 listed companies of holding corporate real estate. In other words, only those 11 companies had more than $20 \%$ real estate holdings in the research period. In addition of the 11 companies, only 5 hotels had completed time series data from 1983 to 2001. As such, the sample of this study is somewhat small. Beside this, there are other factors that affect the systematic risk of hotel sector. In this study, the influence of these factors was excluded because of the original focus of this research. Further research could focus on other countries' hotel markets or other sectors. It would be beneficial if research can be done on larger sample and the factors that lead the percentage of real estate holdings to have positive or negative effects on firms systematic risk can be found out. 


\section{References}

Apgar, M. V. 1995. 'Managing Real Estate to Build Value', Harvard Business Review, Nov/Dec, pp. 2-11.

Barry, V. 1999. 'A Process for the Portfolio Management of Real Estate Assets', Journal of Corporate Real Estate, vol. 2(2), pp.113-22.

Becker, F. and Joroff, M. 1995. 'Reviewing the Workspace', Norcross: Industrial Development Research Foundation.

Carn, N., Black, R. and Rabianski, J. 1999. 'Operational and Organizations Issues Facing Corporate Real Estate Executives and Managers', Journal of Real Estate Research, vol.17(3), pp.281-299.

Duckworth, S. L. 1993. 'Realizing the Strategic Dimension of Corporate Real Property Improved Planning and Control Systems', Journal of Real Estate Research, Fall, pp.409-509.

Estey, R. 1988. 'How Corporate Real Estate Departments Contribute to the Bottom Line', Industrial Development, July-August, pp.4-6.

Hill, M. 2001. 'Corporate Real Estate: Its Role in Maximizing Shareholder Value', Journal of Corporate Real Estate, vol.3(4), pp.335-45.

Joroff, M., Louargand, M., Lambert, S. and Becker, F. 1993. 'Strategic Management of the Fifth Resource: Corporate Real Estate', Norcross: Industrial Development Research Foundation.

Liow, K. H. 1995. 'Property in Corporate Financial Statements: the UK Evidence', Journal of Property Research, vol.12, pp.13-28.

Liow, K. H. 1999. 'Corporate Investment and Ownership in Real Estate Decision', Journal of Corporate Real Estate, vol.1, pp. 4-11.

Manning, C. A. and Roulac, S. E. 1996. 'Corporate Real Estate Research within the Academy', Journal of Real Estate Research, vol.17(3), pp.265-79.

Nourse, H. O. and Roulac, S. E. 1993. 'Linking Real Estate Decisions to Corporate Strategy', Journal of Real Estate Research, vol.8(1), pp.475-494

Roulac, S. E. 2001. 'Corporate Property Strategy is Integral to Corporate Business Strategy', Journal of Real Estate Research, vol.22, pp.129-152.

Roulac, S. E. and Roberts, N. 1990. 'Strategic Priority: Unlock Corporate Real Estate Values', in Gorham, W and Lamont (ed.) Real Estate Outlook.

Seiler, M. J., Chatrath, A. and Webb, J. R. 2001. 'Real Asset Ownership and the Risk and Return to Stockholders', Journal of Real Estate Research, vol. 22, pp.199-212.

Veale, P. R. 1989. 'Managing Corporate Real Estate Assets: Current Executive Attitudes and Prospects for an Emergent Discipline', Journal of Real Estate Research, vol.4(3), pp.1-22.

Virginia A. G. and Barkham, R. 2001. 'Corporate Real Estate Management in the Retail Sector: Investigation of Current Strategy and Structure', Journal of Real Estate Research, vol.22(1/2), pp.107-27.

Zeckhauser, S. and Silverman, R. 1983. 'Rediscovering Your Company's Real Estate', Harvard Business Review, vol. 61(1), pp.111-117. 